\title{
SER HABITADA POR TIMOR
}

Suillan Miguez Gonzalez ${ }^{1}$

A ideia do presente texto é que, inicialmente, o leitor entre em contato com a dimensão catastrófica liderada pelo invasor indonésio junto ao território timorense e conheça as vozes de Xanana Gusmão, João Aparício e Domingos de Sousa por meio da literatura produzida para manter o espírito da resistência, revelando, com isso, as mais cruéis ações humanas praticadas para a impor a anexação da ilha de Timor, em contrapartida da necessidade de reconquista da pátria para o cessar da opressão. Somadas a tais vozes, reconhecidos escritores, como Mia Couto, Sophia Andresen, Craveirinha e Agualusa ofereceram prefácios às obras como gesto solidário à luta pela liberdade da nação, forjando uma rede literária.

O segundo momento refere-se à experiência de viver no Timor pósindependência, por seis meses, o que justifica o estudo oferecido e a promessa feita aos timorenses de que não seriam esquecidos por mim, mas, sim, seriam lidos e admirados: minha tese de doutorado, em andamento, faz do país e de seu povo objeto de estudo e apreciação, na torcida por angariar ou conquistar mais interessados pela temática. Adianto que o relato vem acompanhado por imagens de meu arquivo pessoal, é bem-intencionado e repleto de engasgos não evitados, porque Timor foi o meu despertar para o mundo oriental.

\section{À defesa de Timor-Leste: a rede literária em prol do valor da vida, liberdade e paz}

Há cerca de quarenta anos, metade de uma ilha chamada Timor-Leste ou TimorLorosae - pertencente ao arquipélago de Java, na parte oriental do mundo, mas colonizada por portugueses - é invadida pela Indonésia, precisamente em 1975, na operação nomeada Komodo, cujo objetivo alegado era o de que os dois povos se tornariam, enfim, "sama-sama". Tal termo muito bem representa a postura discordante das partes, já que "sama" significa "igualdade" na língua indonésia, e ironicamente, "pisar/esmagar" no tétum, língua de uso social em Timor.

\footnotetext{
${ }^{1}$ Doutoranda em Estudos Comparados de Literaturas de Língua Portuguesa - Universidade de São Paulo/USP.
} 
Antecedendo o panorama mencionado acima, houve divergências quanto ao momento político mobilizado para a independência da então colônia portuguesa. Partidos políticos foram fundados com frentes e ideais pouco sintonizados, a ponto de fragilizar a ordem local. A esta altura, o governador português entendeu a também estéril situação do colonizador, sombrio na transição do poder. Neste sentido, houve mais uma marcante fuga histórica portuguesa, desta vez de Timor, ao atinarem-se para as intenções expansionistas do ditador indonésio Suharto, apoiado pela Austrália e pela força bélica estadunidense.

A motivação não se centrava na integração cultural dos povos, e sim no rendimento a que se poderia alcançar com a fonte petrolífera do Mar de Timor. Por isso, usaram dos mais diversos instrumentos de guerra, sem declará-la, porque sabiam que enfrentariam uma possível intervenção da ONU, e principalmente, seguros do desinteresse e alienação do resto do mundo.

O fundamento do Estado indonésio girava em torno do Pancasila, diretrizes que definiam o caminho da vida da nação, sendo, resumidamente: i) confiar e crer num único Deus Supremo; ii) cada ser humano ser considerado criatura de Deus que tem igualdade de direito e dignidade; iii) para viver a sua existência, o homem é um ser único; iv) para viver com outros dentro de uma nação, é preciso haver, entre os cidadãos, um comum acordo no tratado das coisas, mediante diálogo, o respeito mútuo e abertura, na efetivação dos direitos e liberdades fundamentais; v) a justiça social é para todo o povo da Indonésia e está acima de tudo. Em tese, e somente em tese, o Pancasila sofreu grave distorção em se tratando do esmagamento do povo de Timor.

O balanço dos vinte e cinco anos de imposição da língua indonésia, da educação militarizada, dos campos de concentração, da fome e doenças, das violações contra as mulheres e crianças, dos roubos, dos massacres, da destruição das casas e dos ícones culturais, foi o de 200 mil timorenses mortos; além da formação e consagração da resistência timorense: guerrilha forjada e recuada nas montanhas, liderada, oficialmente, por Xanana Gusmão; e o exílio, a dispersão de famílias como meio de preservar a vida.

Partindo de uma situação delicada e de impedimento, como a demonstrada, é que se pode pensar que a produção literária timorense é essencialmente de diáspora e de difícil reunião, organização ou mesmo divulgação, para os interessados e para os próprios timorenses que foram inviabilizados por terem suas instituições ruídas e censuradas.

Há de se lembrar do desaparecimento do poeta Jorge Lautém pelo advento da invasão e tantos outros talentos ceifados pela brutalidade dos soldados de Suharto, e 
outros já falecidos como o elevado poeta Fernando Sylvan. Pode-se, então, apontar o caráter fragmentário de um projeto maior de literatura timorense, com interrupções e recomeços a depender da situação política do país. Muitas das obras já publicadas se direcionam a leitores estrangeiros, prova disso são as inúmeras notas de rodapé com traduções de termos em tétum, das línguas distritais ou das siglas dos movimentos partidários com o intuito de contextualizar o público não somente oferecendo a tradução, mas explicações culturais referidas ao povo de Timor.

Mesmo não havendo um movimento coeso de escritores na diáspora, percebe-se que a denúncia quanto às infrações dos direitos humanos realizadas contra o povo timorense é o ponto aglutinador da prosa e poesia. Em verdade, é a militância em prol da liberdade de ser timorense e não indonésio, a reivindicação primeira, para culminar no registro doloroso do que se passou nos vinte e cinco anos da presença forçosa do país vizinho.

A literatura, mais que um objeto artístico, ganhou, no caso de Timor, o papel de mensageira, de divulgadora e agregadora de simpatizantes para a causa de libertação da nação, principalmente, na Comunidade de Países de Língua Portuguesa (CPLP). Publicou-se, com isso, obras dedicadas a reiterar o movimento da resistência, ao mesmo tempo em que estas revisitaram todas as mortes integrantes de uma memória coletiva e histórica permanente, instituída na reestruturação do país a partir do Museu da Resistência Timorense.

Por muito tempo, todas as violações para o aniquilamento de milhares de lestetimorenses foram invisíveis a todos nós, até que um jornalista filmou e divulgou em escala mundial o ocorrido no que ficou conhecido como Massacre do Cemitério de Santa Cruz - 12 de novembro de 1991 -, em que um cortejo de milhares de timorenses acompanhava o enterro do jovem Sebastião Gomes, assassinado por soldados indonésios por protestar contra o regime opressor do invasor. Esse massacre diz respeito ao fuzilamento da maioria das pessoas que se solidarizaram com a coragem de Sebastião em expressar o descontentamento que era, em verdade, de todos. Abriram fogo dentro do cemitério e sem critério algum, mataram crianças, jovens, mulheres, idosos, estrangeiros. As imagens funcionaram como prova cabal para que a omissão dos principais órgãos reguladores de direitos e de intervenção cessasse.

A incansável mobilização dos timorenses Ramos-Horta e Dom Ximenes Belo pela solução justa e pacífica da situação deflagrada no país rendeu o reconhecimento internacional: foram laureados com o Prêmio Nobel da Paz, em Oslo - Noruega, em 1996. 
Houve, à luz de tal acontecimento, a confiança e o apoio de diversos literatos, expressos nos prefácios das obras de timorenses, e mesmo, na produção de romances sobre Timor.

A grata descoberta de verdades culturais sedimentadas na honra, na palavra e na paz da pequena grande nação de Timor-Leste, somada à colonização portuguesa, rendeu às Literaturas de Língua Portuguesa a possibilidade de nova dinâmica: a tomada de atitude solidária, a intervenção pelo direito à liberdade.

A começar pelo prefácio inspirador de Mia Couto para o livro de poesia $\mathrm{Mar} \mathrm{Meu}$ do chefe da guerrilha timorense Xanana Gusmão, no qual lança mão de questionamentos que revitalizam a possibilidade de um mundo menos em pedaços e mais colaborativo: "Neste estilhaçar de tempo e mundo que lugar tem a solidariedade? Quanto nos pode ocupar a injustiça que ocorre distante quando, tantas vezes, fechamos os olhos àquela que tem lugar no nosso próprio lugar?” (GUSMÃO, p. 6, 2003). Responde às indagações pensando no exemplo de Timor:

Timor parece erguer-se como prova contrária a estes sinais de decadência. Afinal, há alma para sustentar causas, erguer a voz, recusar alheamentos. Uma nação distante se reassume como nosso lar, nossa razão, nosso empenho. $\mathrm{O}$ sangue que se perde em Timor escorre de nossas próprias veias. As vidas que se perdem em Timor pesam sobre nossa própria vida (GUSMÃO, p. 6, 2003).

A ocasião da confecção e publicação da obra de Xanana Gusmão, conhecido por liderar a resistência em Timor, é regida por sua prisão efetuada pelos soldados indonésios em novembro de 1992. O julgamento oferecido não permitiu defesa, mas o apenou a prisão perpétua, sendo encarcerado em Cipinang - Jacarta, local da produção das poesias e quadros que compõem o que se tornou o chamado à luta pela libertação nacional. Muitas vozes surgiram e se uniram como reforços a tal convocação e ao combate à impunidade e opressão indonésia.

Sophia Andresen, Agualusa e Craveirinha também se dispuseram a ser prefaciadores de obras literárias de timorenses, mencionando nos respectivos textos como se comoveram com a certeza inabalável destes sobre um futuro democrático e de paz para Timor, ainda que o cenário não fosse nada favorável. Cada qual acaba por relatar como tomou conhecimento da situação do país, bem como das atrocidades sabidas por todos e mesmo assim não impedidas. Andresen foi apresentada a Timor por Ruy Cinatti, desbravador da cultura, natureza e relações com o povo leste-timorense:

O meu primeiro e inesquecível encontro com Timor foi aquela madrugada em que, ao chegarmos em casa, depois de não sei que festa, mal abrimos a porta 
da rua fomos surpreendidos por um barulho de vozes e risos. E quando abrimos a porta da sala vimos os nossos filhos - ainda pequenos - e a queridíssima criada Luísa sentados no chão em roda de Ruy Cinatti que tinha ao seu lado uma mala de onde iam saindo tecidos, objetos de madeira, caixas, pequenas estatuetas, punhais - e naquela noite de Lisboa cheirava de repente a sândalo. (...) me sentei no chão a ouvir as histórias de Timor, das árvores, das flores, dos búfalos, das fontes, das danças e dos ritos" (APARÍCIO, p. 11, 1999).

A escritora portuguesa se indigna com a falta de posicionamento da comunidade internacional, o que chama de "muro de silêncio", diante do crime cometido pela Indonésia: "Mas pior do que tudo foi, durante muitos anos, a surdez das grandes potências democráticas defensoras dos direitos humanos" (APARÍCIO, p. 14, 1999).

Em tom mais atenuado, porém ao encontro da postura de Sophia Andresen, Agualusa escreve o prefácio de Crónica de uma travessia - A época de Ai-Dik-Funam obra de estreia do romancista timorense Luís Cardoso, faz alusão ao momento do primeiro contato entre ambos e da convicção inexplicável da reconquista do território tomado:

Conheci o Luís Cardoso em 1981, no Instituto Superior de Agronomia. Naquela época, Timor era ainda um lugar fora do mundo. Os guerrilheiros de Xanana Gusmão morriam nas montanhas sem que ninguém o soubesse - pior, sem que ninguém quisesse saber. Por vezes Luís falava do futuro como se houvesse futuro. Aquela espécie de esperança, feroz, determinada, à revelia do mais elementar bom senso, parecia-me uma doença. Ele, porém, defendia as suas posições com a paciente gentileza de um príncipe oriental, de tal maneira que a mim só me restava fingir que acreditava nele. Passaram-se quinze anos e o tempo deu razão àquela esperança. Hoje, Timor ocupa as atenções de uma parte importante do mundo, e quando um guerrilheiro dispara a sua arma, nas montanhas, o eco desse tiro ouve-se em Jacarta. (CARDOSO, p. 8, 1997)

Por sua vez, Craveirinha se manifesta no prefácio de Andanças de um timorense - romance de Ponte Pedrinha - sobre o poder da palavra que é vivida, porque é incontestavelmente sincera. Aponta o advento da invasão e diante disso "a negação da letargia e o redescobrir da luz do sol no belo espaço de uma Pátria, a Pátria autêntica" (PEDRINHA, p. 2, 1998), para completar com a declaração da ciência de que TimorLeste "se fez de sangue, sacrifícios e luta" (PEDRINHA, p. 2, 1998) desde 1975.

A legitimação do conjunto de obras referidas compõe uma rede literária de solidariedade, em defesa à vida, à liberdade e à paz retiradas da rotina pacífica de uma civilização insular, cuja organização social e política é sólida e pautada nas tradições dos antepassados, no pacto com a verdade, na importância da honra, na formalidade das cerimônias, na cristianização portuguesa.

Tomando como fundamentais essas publicações de apoio aos escritores timorenses, é interessante que se parta, então, para conhecer as suas vozes . Xanana 
Gusmão fez de Mar Meu um instrumento de comunicação e motivação contundente para uma espécie de nova convocação para a resistência, no Timor e no mundo. Os versos de Gusmão funcionaram como o próprio flagrante da repressão indonésia contra seu povo, gerando imagens devastadoras de tortura no poema "Gerações":

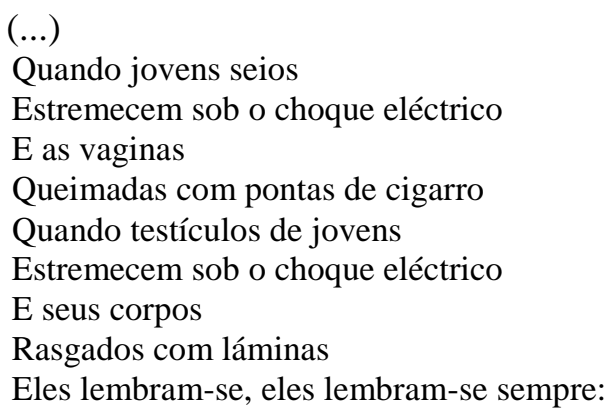

Outras tantas formas de silenciamento e aniquilação da dignidade humana foram utilizadas para o fortalecimento do medo e coação de um desejo inexistente de anexação territorial. Não havia limites para as atrocidades cometidas ou qualquer demonstração do valor à vida, ou melhor, do direito à vida em se tratando da política expansionista indonésia. Ainda, na mesma poesia, o poeta continua a descrever a desenfreada disposição para a bestialidade do intruso:

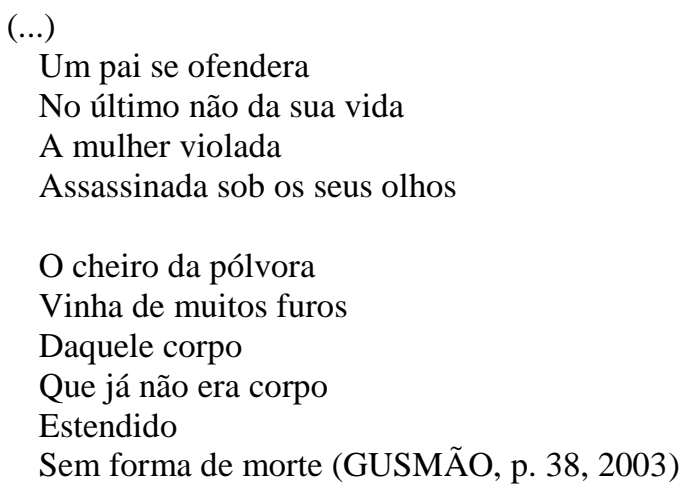

Um outro canto por justiça e paz surge com João Aparício em À janela de Timor, em que não somente traz a resistência como ideologia compatível à retomada da soberania do território, mas conduz algumas de suas poesias a homenagear o líder da guerrilha Xanana Gusmão, figura recorrente em se tratando da produção literária timorense no recorte temporal em questão.

O sucinto poema "Xanana” demonstra o alcance da luta empreendida por um povo para libertar-se, ainda que as garantias de direitos sejam universais, em Timor, 
inexistiram, e vergonhosamente, significaram mais um retrocesso para a história da Humanidade: “A ponta da tua baioneta,/Atinge todo o planeta” (APARÍCIO, p.33, 1999).

Em tom lírico, Aparício não recua quanto à denúncia dos arrastões de mortes instaurados no próprio país, na comovente poesia "Aldeia das crianças":

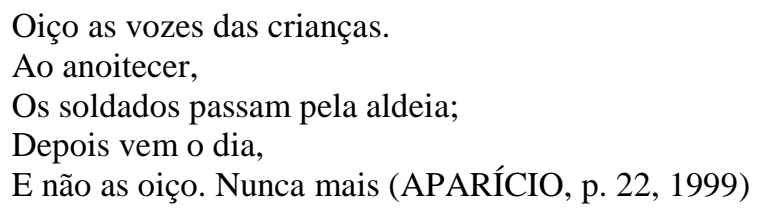

A retratação da relação de intolerância do exército indonésio frente a inocentes marcou a impossibilidade de cultivar qualquer aproximação entre os povos. E, por isso, o triste teor verídico da cena contida nos versos de "A criança de Timor":

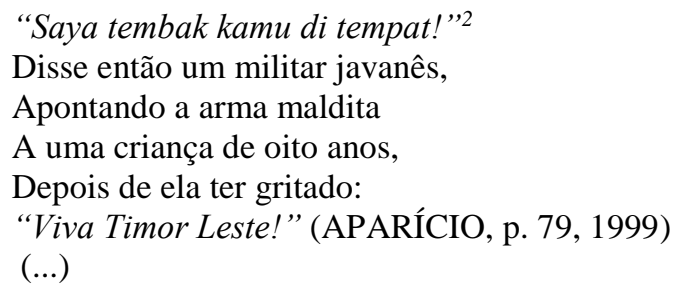

Da poesia para a prosa, Domingos de Sousa se dedicou a elaborar o mais coerente dos heróis timorenses como personagem, invertendo a expectativa de uma trajetória marcada por virtuosidade, Colibere, - também título do romance - é o resultado de uma guerra desigual que leva à degradação do ser humano. Passou de mensageiro da guerrilha a prisioneiro em um campo de concentração; de torturado a assassino da mãe; de tresloucado inofensivo a mendigo em Díli; de timorense a total invisibilidade e indigência na multidão.

Rica em detalhes, a narrativa reconstrói a memória do povo timorense em meio à deflagração do caos, da prática da animosidade como recurso de imposição da nova gestão. Colibere é a grande testemunha da destruição da cultura, da própria aldeia, e em maior escala, do país:

Foi assim que Colibere viu com os seus próprios olhos como os invasores destruíram os livros nas escolas, queimando-os, servindo-se deles para fazer fogueiras e aquecer água para fazer chá e cozer massa. As escolas sofreram pilhagens e destruição de toda a ordem (SOUSA, p. 70, 2007).

\footnotetext{
${ }^{2}$ Em indonésio significa: "Atiro-te morto no lugar".

Revista Crioula USP, $\mathrm{n}^{\circ} 17$, junho de 2016
} 
Há passagens chocantes, em que a humilhação do já prisioneiro Colibere e colegas chega ao nível do inimaginável, o desespero é dominante e a vontade de morrer torna-se o melhor remédio para findar com o masoquismo do exército indonésio:

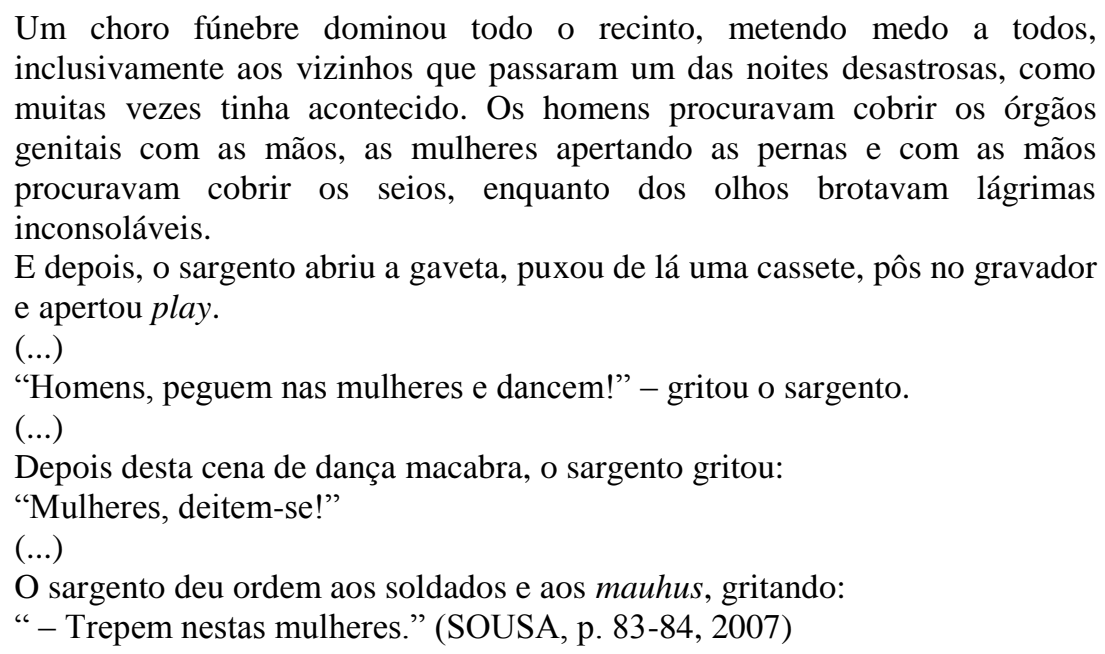

Não há arma de guerra mais poderosa que o rebaixamento do ser humano pelo próprio ser humano. A literatura produzida como compartilhamento da dor tornou-se o ponto de partida para as obras em Língua Portuguesa de Timor-Leste.

\section{Timor foi o meu despertar}

Desembarquei em Díli, capital de Timor-Leste, na segunda quinzena de janeiro de 2012, em missão para a Cooperação Brasileira junto de um programa para qualificação docente no país. Entre atrasos e contratempos, a viagem durou cerca de 4 dias, os mais ansiosos de minha vida, porque sabia que os dois livros nos quais me pautei, lidos aqui no Brasil, poderiam não dizer tudo. O Timor no qual pisei já somava dez anos de independência, apesar da presença dos soldados da ONU para a manutenção da segurança nacional. O primeiro-ministro de Timor, Xanana Gusmão, ex-guerrilheiro da resistência e ex-prisioneiro dos indonésios, lutava, agora, para acelerar a estruturação do Estado. 


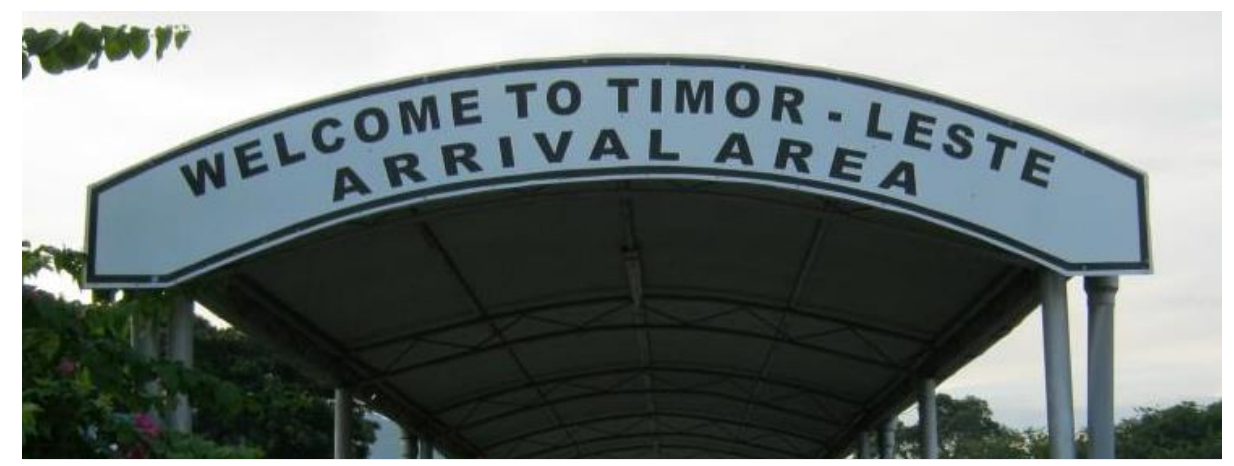

No primeiro mês vivendo em Díli, optei por observar com o intuito de vislumbrar a cadência de vida que levavam, visitei uma escola, em pleno sábado, que estava oferecendo aos estudantes aula de ginástica, cujo áudio ritmava os movimentos dos braços (aprendi a contar em tétum), num mar de pura vida. Não consegui me comunicar porque as crianças não falavam e nem entendiam Português, no entanto, soltavam boas gargalhadas quando viam a imagem delas captada na câmera fotográfica. Havia receptividade em tantos sorrisos.
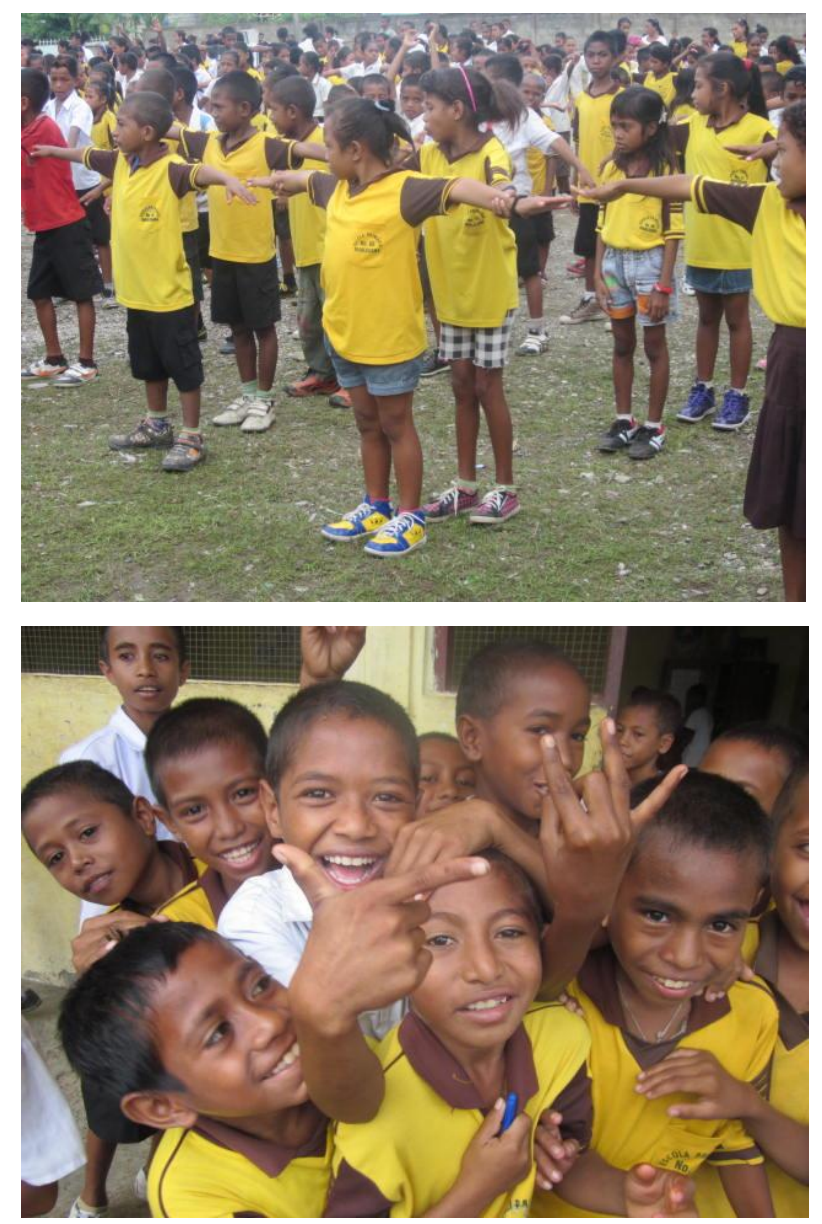

Regressei de microlet rosa - repleta de pôsteres de jogadores de futebol e sonoridade peculiar para anunciar a passagem - trata-se de transporte coletivo destinado aos timorenses, mas que pude entrar por estar vazia. Logo na entrada, rachei a cabeça em 
uma ponta sobrante no teto, coisa de malai (estrangeiro), que não possui as dimensões necessárias para naturalmente caber no veículo.

Em outra oportunidade, convidada por uma colega brasileira, acompanhei-a a uma lulik (casa sagrada), onde estava ocorrendo o ritual da colheita do milho, momento de oferecer aos antepassados oferendas para garantir a fertilidade na agricultura e alimento para a família. O anúncio do início do ritual acontecia por meio do sopro do chifre de búfalo pelos mais velhos, que se apresentavam em traje tradicional (tais) e permaneciam guardando as mais diversificadas oferendas. As mulheres se encontravam cozinhando o milho colhido na cortina de fumaça densa da área coberta. O porco sacrificado estava sendo limpo do lado de fora para a composição do banquete de mais tarde. Já as crianças brincavam, corriam sempre livres e constantes na alegria.
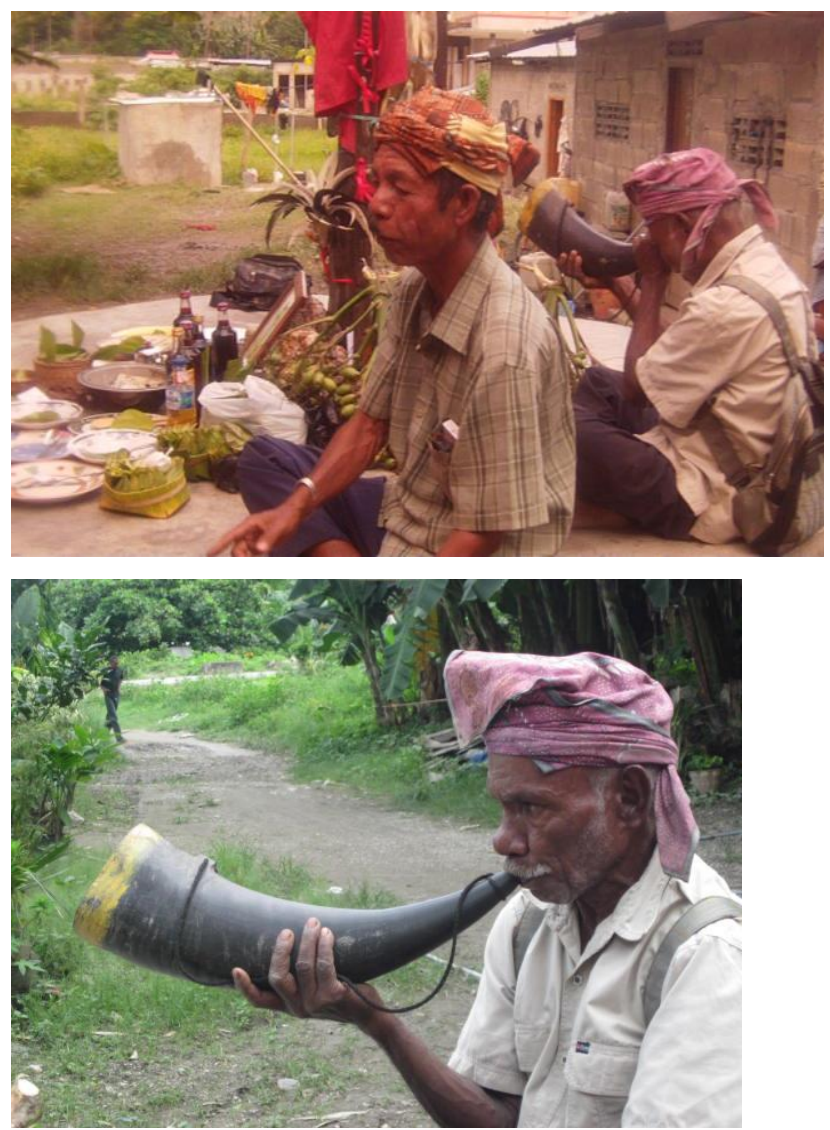

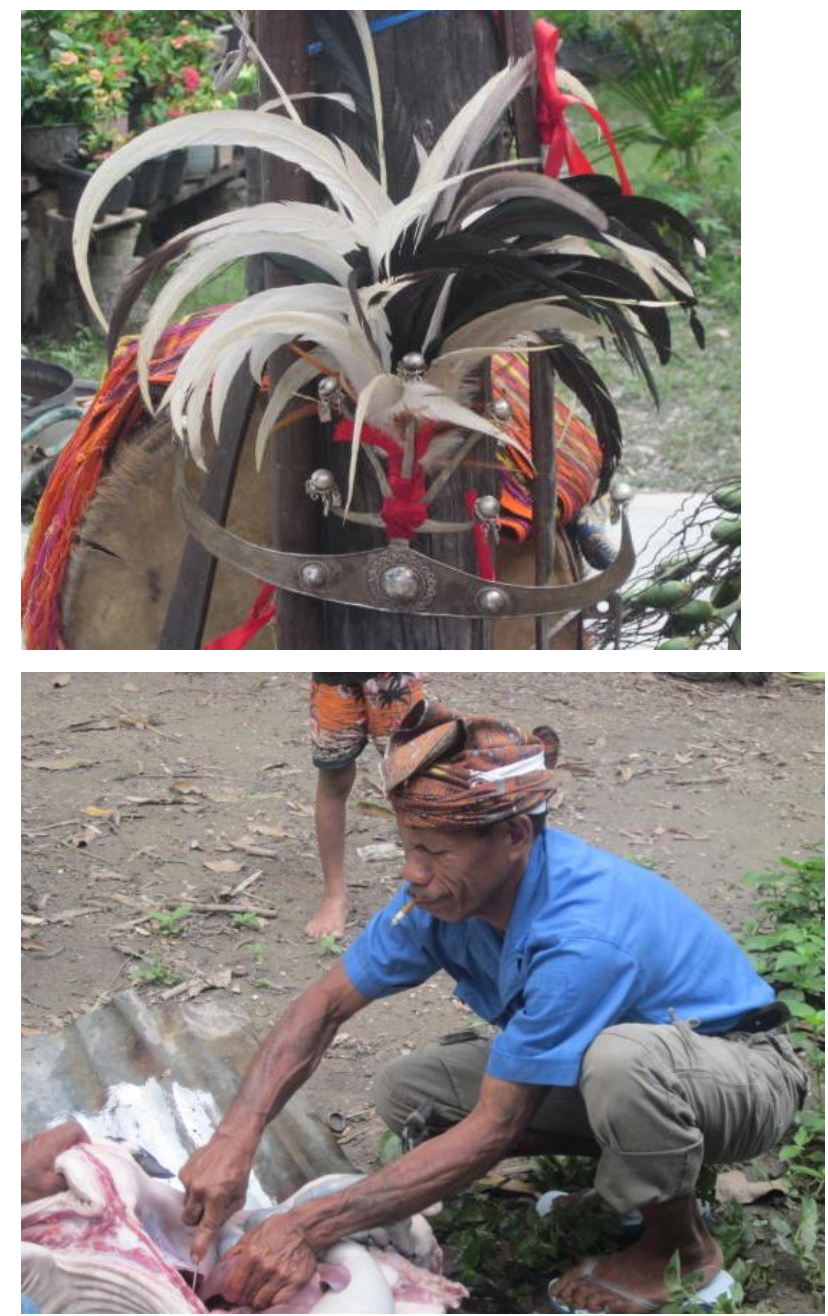

Revista Crioula USP, $\mathrm{n}^{\circ} 17$, junho de 2016 

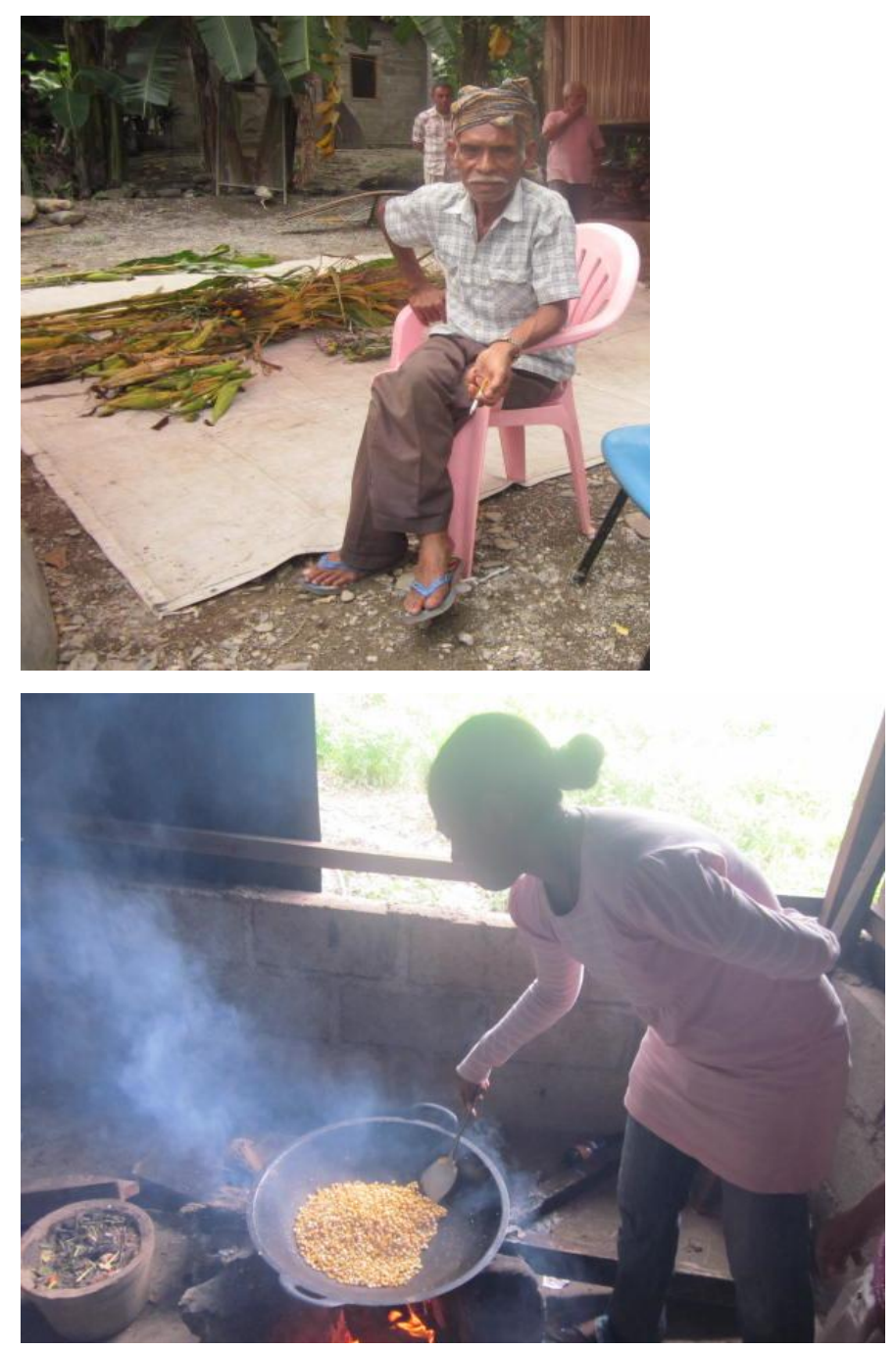

Caminhei muito dentre a poeira levantada pelo carros e motos que circulavam pelas ruas, todos muito respeitosos. Houve a surpresa de um grupo de crianças que se aproximou de mim para tocar a minha pele branca, esfregar as mãozinhas para pegar do pigmento e passar como um creme nos rostinhos e bracinhos, para, então, proporem que eu experimentasse me bronzear de terra para me tornar mais escura e ser mais timorense e menos estrangeira.

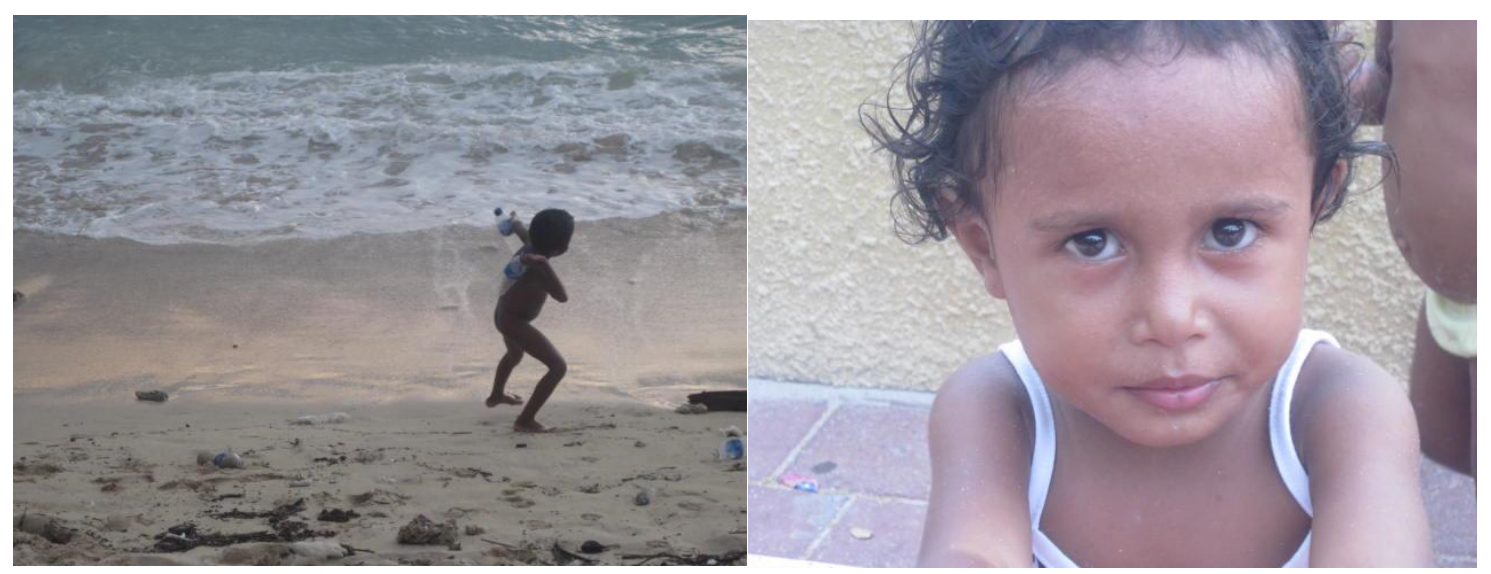




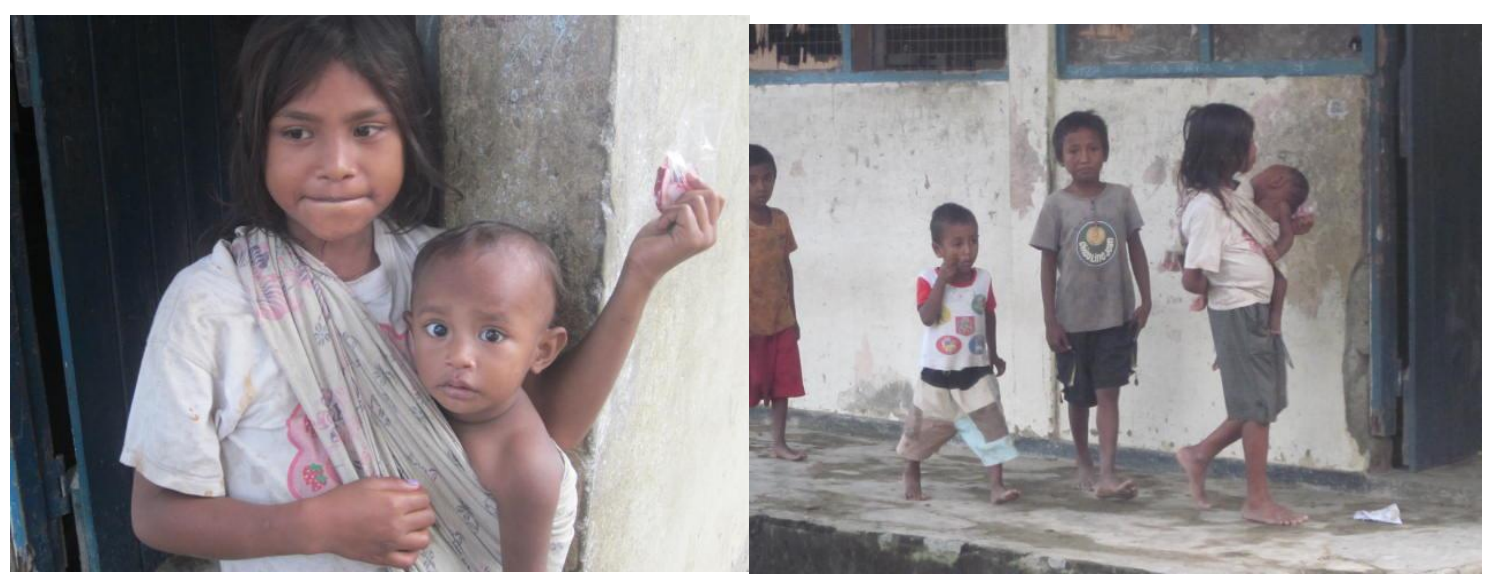

As transações comerciais em Díli se davam somente em dinheiro, daí a necessidade de ir ao banco resgatar o montante do pagamento. A configuração do cenário é, no mínimo, incompreensível por nós ocidentais, digo isto, porque havia pilhas de notas de dólares sistematicamente alinhados nos balcões do banco, dinheiro a ser contabilizado pelos funcionários. Tudo muito exposto e inimaginável em nosso contexto de fortificação de tudo. Os timorenses caminham nas ruas com sacolas plásticas transparentes com o rendimento do mês para depósito, sem qualquer tensão ou preocupação com roubo.

Sabendo da situação de reconstrução do país, da pobreza monetária chegando ao nível da miséria, este contexto não corrompeu os valores de um povo, cuja tradição voltase para a honra e cumprimento da palavra. Percebi que nem mesmo os vinte e cinco anos de opressão indonésia foram capazes de mudar um sentido maior de integridade e respeito ao próximo.

Os relatos compartilhados por colegas de docência timorenses sobre o sofrimento de assistir ao dizimar da família pelos soldados indonésios ou mesmo as torturas, a vivência nos buracos nas montanhas como guerrilheiros, presenciar a destruição de reinos inteiros, para então testemunhar a conquista pela independência, fez com que um amigo timorense se interessasse pela história do Brasil e me perguntasse qual era o nosso herói da independência. Constrangida, disse que não havia um, já que nem mesmo o povo brasileiro participou de tal evento histórico. Percebi, de pronto, as expressões confusas geradas pela minha resposta, e que, no íntimo, não acreditaram em mim por não conceberem uma nação que não lutasse pela própria independência.

Outro episódio marcante foi o inesperado convite para participar de um casamento timorense, digo inesperado porque a comunicação com esta mulher timorense se dava apenas por mímica, sorrisos, expressão facial, não encontramos uma língua em comum, o que não impediu que a amizade florescesse. Compareci com colegas brasileiros no casamento realizado na Igreja Católica e seguido de festa timorense no interior do suco 
(o equivalente a bairro ou comunidade). Fomos muito bem tratados ao ponto da pequena banda nos homenagear com músicas brasileiras., Havia uma organização para a dança, os homens faziam o pedido às mulheres que esperavam sentadas. As comidas e refrigerantes estavam meticulosamente postos, duas filas se formaram naturalmente e de forma paciente todos se serviram. Galinhas caramelizadas emprestaram forma como coração centralizado à mesa, houve discurso da família para os noivos, assim como a dança especial deles, tudo seguindo a pertinência das formalidades da cerimônia. Eu e meus colegas decidimos presentear o casal com um álbum de fotos que registraram a ocasião.
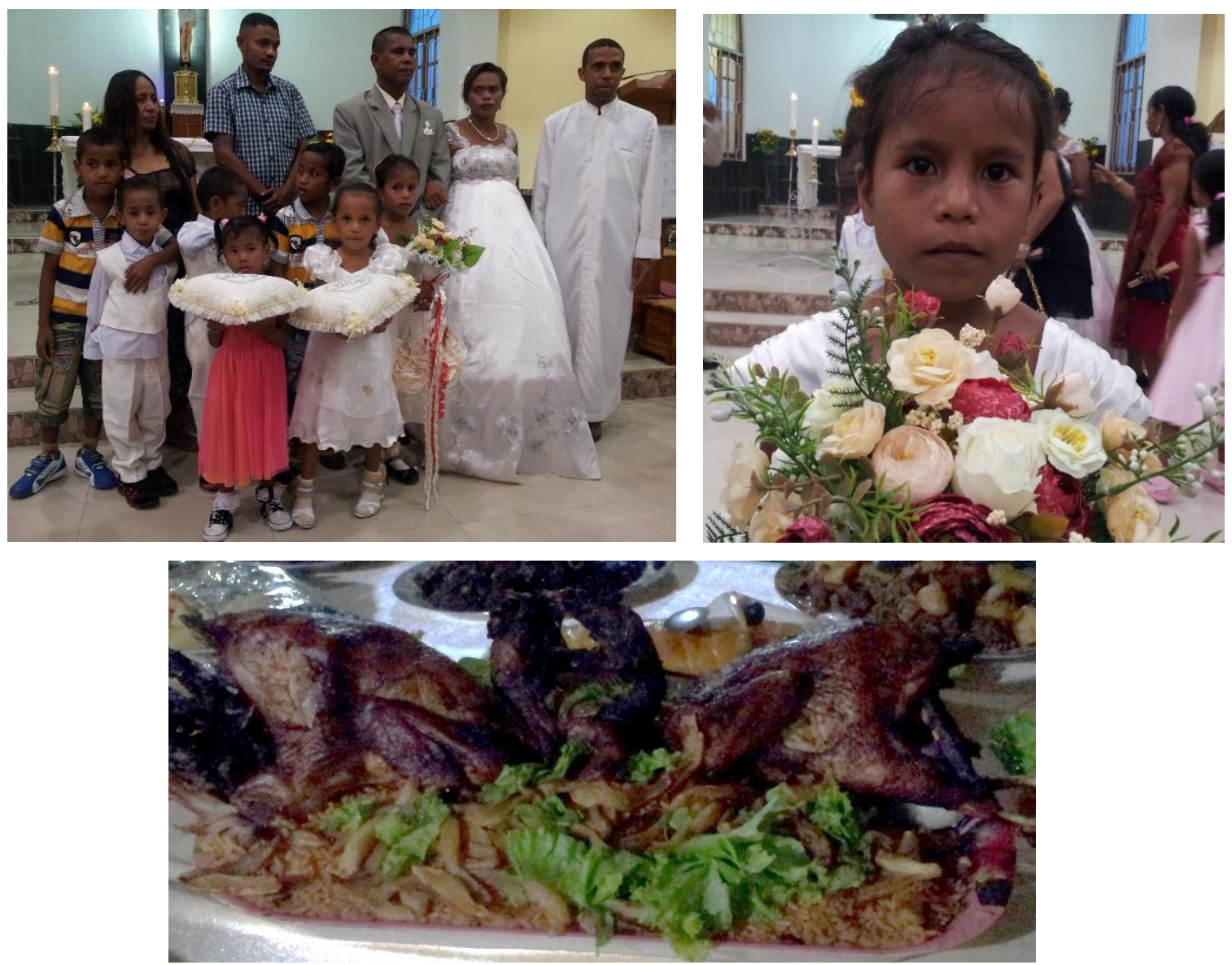

$\mathrm{Na}$ tradição timorense, é necessário que se pague o barlak, equivalente ao dote, para a família da noiva, a depender do distrito a que a pretendente se origina, o montante varia para mais ou menos. Isso faz com que eu me recorde de uma indagação curiosa feita por uma colega recém-chegada a Timor a algumas jovens timorenses: "Vocês já encontraram o príncipe encantado?". Nesta ocasião, constatei o quão idealizamos o amor, tão mais praticado em Timor, ao mesmo tempo que acordado socialmente.

Quanto a minha contribuição para a Educação, fui designada para trabalhar com docentes em uma escola da periferia de Díli do Ensino Secundário (nosso Ensino Médio), em que a maior dificuldade foi a falta de fluência em Língua Portuguesa destes e dos Revista Crioula USP, $\mathrm{n}^{\circ} 17$, junho de 2016 
estudantes. A infraestrutura era condizente com a retaliação realizada pela Indonésia em sua saída devastadora, já que atearam fogo em tudo. Para o mínimo funcionamento da unidade escolar, repararam as salas de aula, não havendo sanitários ou qualquer outro espaço de convivência que não sejam ruínas. Cerca de 70 alunos preenchiam cada sala de aula e, ainda que a lotação fosse demasiada, a disciplina imperava. A lousa e o giz ofereciam o conhecimento científico sob as diretrizes impostas pelos indonésios, principalmente nas Ciências Exatas, porque a maioria dos professores seguia o escasso material oferecido pelo regime anterior. A retomada da aplicação do currículo timorense estava em processo, assim como a aquisição do Português.

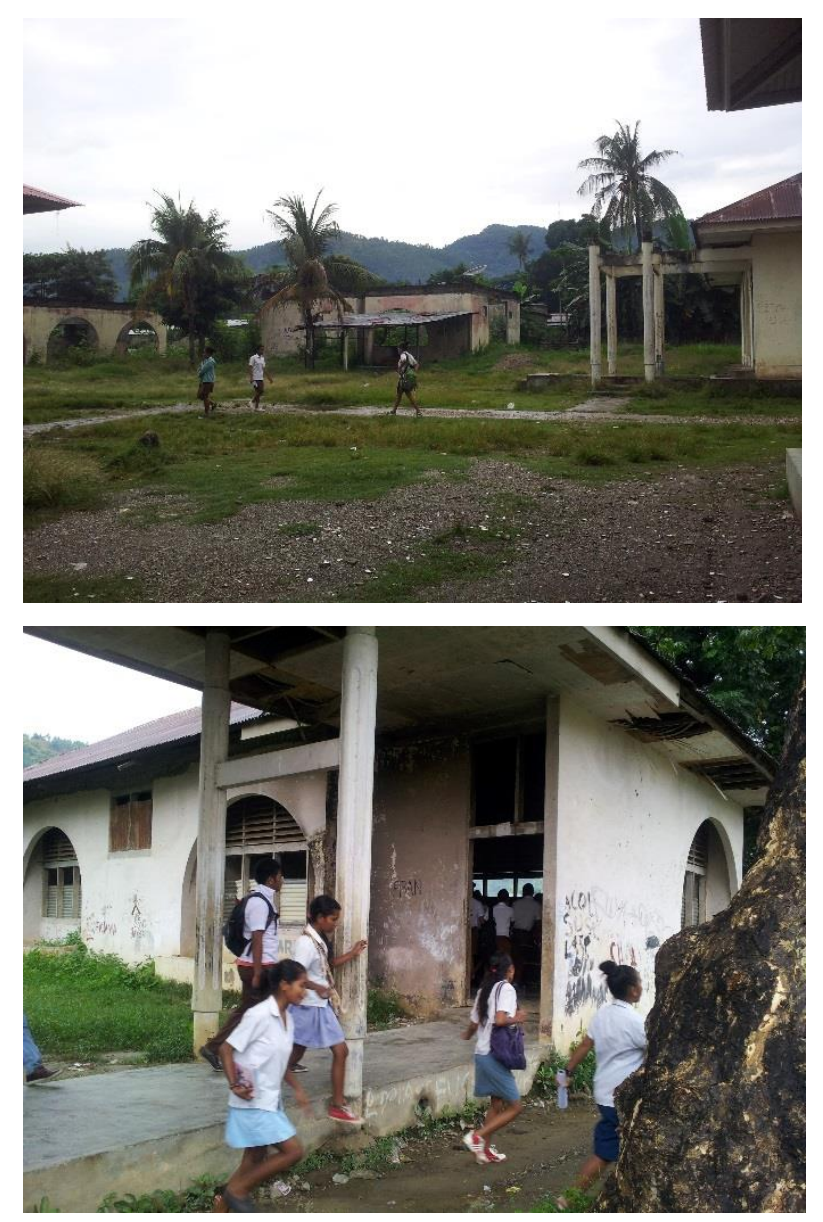

A não circulação de livros era fato no país como um todo. Em uma dada aula, perguntei aos meus alunos quantos livros possuíam em casa, apenas um timorense levantou a mão e disse que a Constituição de Timor-Leste era a única obra que a família teve acesso. No dia seguinte, este mesmo estudante me presenteou com o único livro que já possuiu na vida, e que de tanto o ler memorizou-o por completo. Eu e minhas colegas solicitamos, à pequena biblioteca da Embaixada do Brasil no país, alguns livros de literatura brasileira para distribuirmos aos nossos alunos. 
Tais estudantes estavam matriculados para as nossas aulas de Língua Portuguesa e Cultura Brasileira, porque deveriam ser preparados para virem às universidades no Brasil se graduarem. Tivemos que contextualizá-los quanto às tensões sociais e o cuidado com a possibilidade de serem assaltados, por exemplo. Entretanto, o que nunca esquecerei foi a visita de nossos estudantes a um restaurante de comida brasileira em Díli, custeado por nós, docentes. Grande parte deles nunca havia ido a um restaurante, muito menos, tido a oportunidade de comer algo diferente a que estavam acostumados. O sal e o feijão não os agradaram, mas se arriscaram a comer com garfo e faca e foram brilhantemente bem-sucedidos.

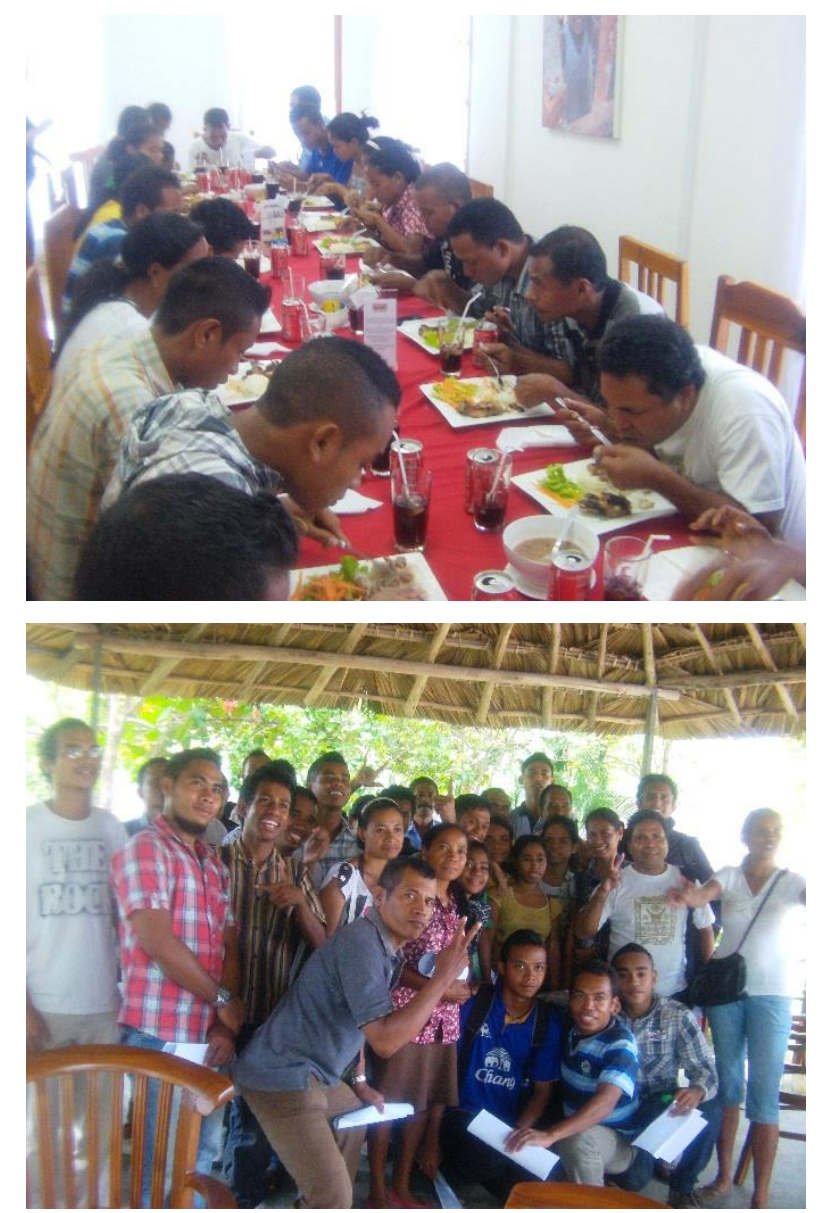

A esta altura, já estava avassaladoramente habitada por Timor. Tão logo se passaram e o encerramento dos cursos de cultura brasileira/língua portuguesa e formações de professores ganharam cerimônias. Em uma delas, dançamos em roda com trajes típicos presenteados pelos nossos queridos alunos, as vozes deles cantaram absolutamente harmoniosas, a ponto de um sentimento de paz surgir, somado a um fundo doloroso de despedida. 

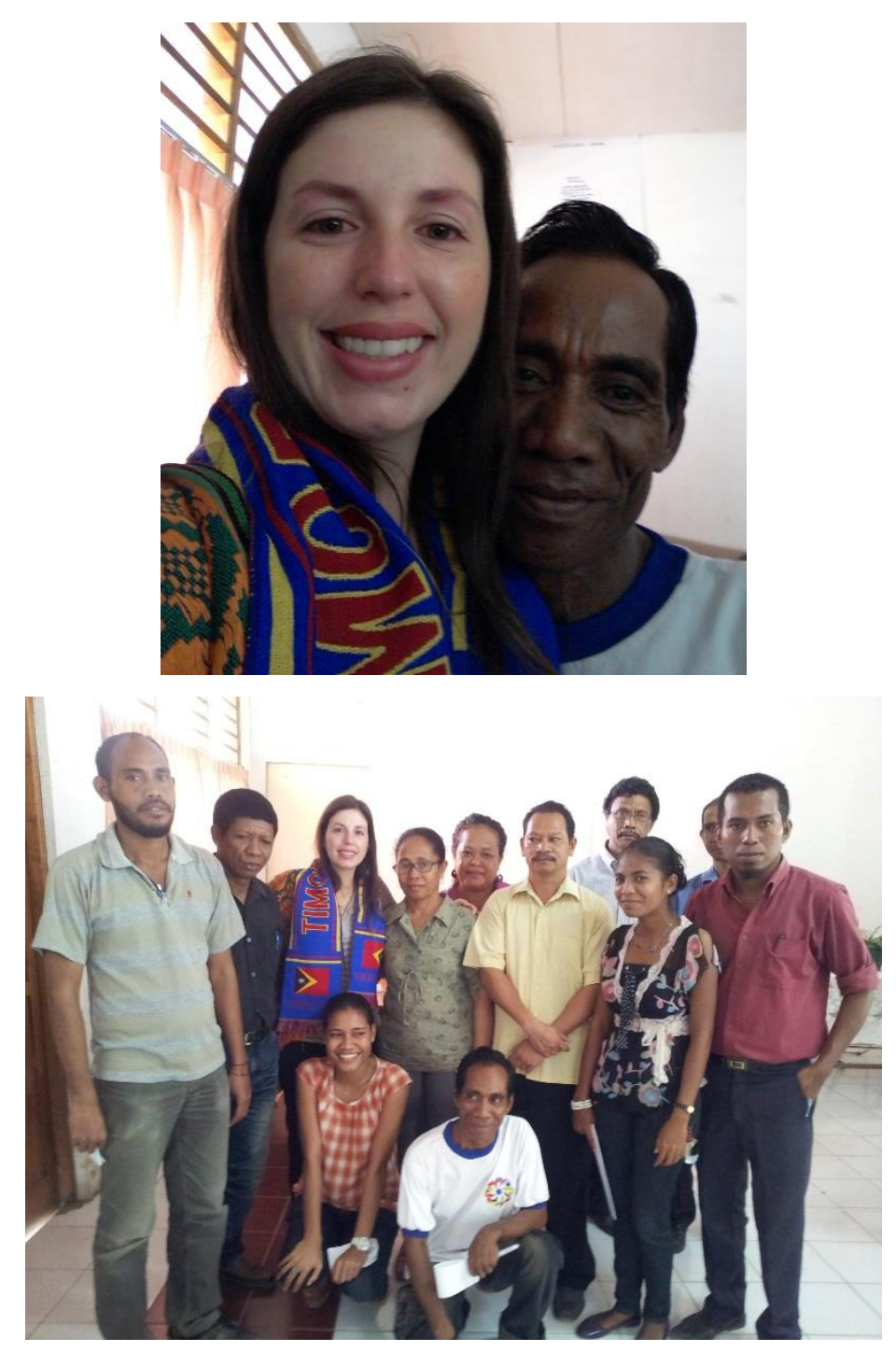

A cada cerimônia de encerramento, um esforço homérico era feito por mim para trancar as lágrimas, até que duas canções entoadas pelos estudantes romperam um rio represado, que reconhecia a minha pequenez em detrimento da almamundo (termo utilizado por Joana Ruas) de um povo que não se resignou diante do holocausto vivido, e que reservou algumas lágrimas para chorar a minha insignificante partida frente aos inúmeros "adeus" em definitivo que foram forçados a dar. 


\section{Referências bibliográficas}

APARÍCIO, João. À janela de Timor. Lisboa: Caminho da Poesia, 1999.

CARDOSO, Luís. Crónica de uma travessia - A época de Ai-Dik-Funam. Lisboa: Publicações Dom Quixote, 1997.

GUSMÃO, Xanana. Mar Meu. Lisboa: Granito, Editores e Livreiros, 2003.

PEDRINHA, Ponte. Andanças de um timorense. Lisboa: Edições Colibri, 1998.

SOUSA, Domingos de. Colibere, um herói timorense. Lisboa: Lidel, 2007. 